\title{
FRITZ SCHÜTZE'S AUTOBIOGRAPHICAL NARRATIVE ANALYSIS APPLIED TO NURSING RESEARCH
}

\author{
Gisele Cristina Manfrini Fernandes ${ }^{1}$, Ivonete Teresinha Schülter Buss Heidemann ${ }^{2}$ \\ Maria Fernanda Baeta Neves Alonso da Costa ${ }^{3}$, Renata Machado Becker ${ }^{4}$, Astrid Eggert Boehs ${ }^{5}$
}

${ }^{1}$ Ph.D. in Nursing. Professor, Departamento de Enfermagem,Universidade Federal de Santa Catarina (UFSC). Florianópolis, Santa Catarina, Brasil. E-mail: gisele.manfrini@ufsc.br

2 Ph.D. in Public Health Nursing. Professor, Departamento de Enfermagem, Programa de Pós-Graduação em Enfermagem, UFSC. Florianópolis, Santa Catarina, Brasil. E-mail: ivonete.heidemann@ufsc.br

${ }^{3}$ Ph.D. in Collective/Public Health. Professor, Departamento de Enfermagem, UFSC, Florianópolis, Santa Catarina, Brasil. E-mail: mafebaeta@gmail.com

${ }^{4}$ Master' student in the Programa de Pós-Graduação em Enfermagem, UFSC. Nurse in the municipal of Florianópolis. Florianópolis, Santa Catarina, Brasil. E-mail: renatamachado19@gmail.com

${ }^{5}$ Ph.D. in Nursing. Retired Professor, Departamento de Enfermagem, UFSC. Florianópolis, Santa Catarina, Brasil. E-mail: astridboehs@ gmail.com

\begin{abstract}
Objective: an experience report with families after natural disasters to present the adapted application of autobiographical narrative analysis in nursing research, proposed by Fritz Schütze.

Method: to describe the process of obtaining narratives followed by the adaptations steps of method application.

Results: six cases of families from a rural area of southern Brazil were surveyed one year after the disaster which resulted in deaths and material losses. The first step was the formal text analysis. The second, was the accurate analysis of each narrative segment. The third phase consisted of the analytic abstraction with the reconstruction of the families' stories. The fourth step recaptured the discussion segments of narratives and theoretical explanations developed by the informants about the disaster. The fifth step summarized the comparison among different cases.

Conclusion: the method offers support for interviews and in-depth analysis of health and disease narratives and their social context. Its potential for application to nursing research highlights attitudes and life changes in the face of crisis and suffering, based on experiences of individuals in groups such as families and communities.
\end{abstract}

DESCRIPTORS: Nursing. Autobiography. Narratives. Families. Disaster.

\section{ANÁLISE DE NARRATIVAS AUTOBIOGRÁFICAS DE FRITZ SCHÜTZE APLICADA À PESQUISA EM ENFERMAGEM}

\section{RESUMO}

Objetivo: relato de experiência com o objetivo de apresentar a aplicação adaptada da análise de narrativas autobiográficas proposta por Fritz Schütze com famílias no pós-desastre natural na pesquisa em enfermagem.

Método: descreve-se primeiramente o processo de obtenção das narrativas, seguido das adaptações dos passos de aplicação do método. Resultados: foram pesquisados seis casos de famílias de uma área rural do sul do Brasil, um ano após o desastre no qual houve mortes e perdas materiais. O primeiro passo foi a análise formal do texto. O segundo, a análise minuciosa de cada segmento de narrativa. $\mathrm{O}$ terceiro consistiu na abstração analítica com a reconstrução das histórias das famílias. O quarto passo resgatou os segmentos argumentativos das narrativas e as explicações teóricas desenvolvidas pelos próprios informantes sobre o desastre. O quinto passo resumiu-se na comparação entre os diferentes casos.

Conclusão: este método oferece subsídios para a entrevista e análise aprofundada das narrativas da saúde e da doença e seu contexto social. O seu potencial de aplicação na pesquisa de enfermagem destaca o desvelar das atitudes e das mudanças de vida frente à crise e ao sofrimento, a partir de vivências de indivíduos em grupos como famílias e comunidade.

DESCRITORES: Enfermagem. Autobiografia. Narrativas. Famílias. Desastre. 


\title{
ANÁLISIS DE LAS NARRATIVAS AUTOBIOGRÁFICAS DE FRITZ SCHÜTZE APLICADAS A LA INVESTIGACIÓN EN ENFERMERÍA
}

\begin{abstract}
RESUMEN
Objetivo: relatar experiencias para presentar la aplicación adaptada del análisis de narrativas autobiográficas propuesta por Fritz Schütze con las familias en el post-desastre natural, en la investigación en enfermería.

Método: primeramente, se describe el proceso de obtención de las narrativas, seguido por las adaptaciones de los pasos de aplicación del método.

Resultados: se investigaron seis casos de familias de un área rural del sul del Brasil después de un año del desastre en el que ocurrieron muertes y pérdidas materiales. El primer paso fue el análisis formal del texto. El segundo paso fue el análisis minucioso de cada segmento de la narrativa y el tercero consistió en la abstracción analítica con la reconstrucción de las historias de las familias. El cuarto paso rescató los segmentos argumentativos de las narrativas y las explicaciones teóricas desarrolladas por los propios informantes sobre el desastre. El quinto paso se resumió a la comparación entre los diferentes casos.

Conclusion: este método ofrece subsidios para la entrevista y el análisis profundo de las narrativas de salud, enfermedad y su contexto social. Su potencial de aplicación en la investigación de la enfermería destaca las actitudes y los cambios de la vida frente a la crisis y al sufrimiento, a partir de las vivencias de los individuos en grupos como familias y comunidad.

DESCRIPTORES: Enfermería. Autobiografía. Narrativas. Familias. Desastre.
\end{abstract}

\section{INTRODUCTION}

In recent decades, health researchers, especially nursing researchers, have relied on the social sciences, notably anthropology and sociology, to understand the experiences of their clients. This made it possible to give greater importance to the narratives and to understand that they need to be analyzed with reference to the context of the people. ${ }^{1}$ Analyzing these narratives allows health professionals to build their knowledge regarding certain themes and situations that people go through. This makes it possible to anticipate care and to have an active, adequate participation, interfering or not interfering where there may be some risk to health.

Thus, Brazilian researchers in the health area have sought out authors to leverage methods of interviewing and analyzing narratives. One of the authors that attracted attention was the sociologist Fritz Schütze, with his publications regarding narrative analysis. The author's method is based on Symbolic Interactionism, Social Phenomenology and Social Ethnomethodology. From this perspective, the author understands that the explanation of social phenomena cannot be without the perspective of individuals. Therefore, Schütze and his work group contributed to the resumption of biographical research.

The method is anchored in two theoretical frameworks: narrative theory and biographical theory. According to narrative theory, there are three phases, which are narrative, description, and argumentation. Biographical theory is systematized into analytical categories called structured biographical processes or rather, the narrative analysis is directed to the central elements that shape the biographies and that are relevant to the understanding of the positions and roles occupied in the social structure, understanding of the contexts in which the narratives were constructed, and the factors that produce the changes and motivate actions in the course of life..$^{2-3}$

Fritz Schütze also coordinated research on health topics, for example, the possibility of highlighting the project on the pedagogical role of physicians in relation to their patients with chronic diseases, such as myocardial infarction and breast cancer. ${ }^{4}$

In Brazil, the stages of the narrative interview as conceived by Fritz Schütze were first made explicit in Portuguese in a publication ${ }^{5}$ which prompted Brazilian researchers in sociology, education, psychology and nursing to seek further aids to use such a method.

In the area of health and nursing, some studies $^{6-10}$ have used the method proposed by Fritz Schütze in their research. A study examining the disease experiences of patients with chronic myeloid leukemia, focusing on the dimensions that indicate the beginning of the disease as a biographical rupture, ${ }^{6}$, with elderly, ${ }^{7}$ with families who suffered losses due to a natural disaster, ${ }^{8}$ high risk new mothers with their hospitalized newborn ${ }^{9}$ and on fatherhood in adolescence. $^{10}$

The objective of this paper is to present the adapted application of autobiographical narrative analysis proposed by Fritz Schütze, with families in a post-natural disaster scenario.

\section{PROCEDURE FOR OBTAINING NARRA- TIVES}

The context of the study in which the narratives were obtained was a rural locality of the Médio Vale do Itajaí-SC (Brazil), affected by a natural disas- 
ter in 2008 which caused floods and landslides. The impact of the event was very significant, considering the number of deaths (more than 100 deaths) and the number of homeless people who remained in temporary shelters for long periods of time who needed help to recover economically due to the damages in property, work and community environment, in addition to mourning for personal and family losses. The emotional health of the families was shaken with the unexpected experience, with repercussions in acute situations of disease that were manifested predominantly during the stay in the shelters, affecting the children in particular. Symptoms such as insomnia, depression and anxiety have been reported, justifying the increased use of psychotropic medications by women and adults, as well as worsening chronic disease in the elderly (cardiovascular diseases, for example).

The family life cycle is the process of living in a social group, in which tasks and roles are continually experienced for it to function over time. The dynamics and structure of family arrangements undergo changes that can be expected or unexpected, consisting of phases of transition or crisis. In the present research, it was assumed that the experience of the crisis of a natural disaster caused an unexpected transition, in which unforeseen changes motivated modifications or adaptations in the family routine, in the care rituals and in the structure of the relationships.

We understand that normative transitions in the life cycle are also termed maturational (expected) events, such as marriages, births, becoming an adult, often marked with religious and ethnic or secular rituals. On the other hand, many families are faced with idiosyncratic (unexpected) life cycle transitions, also called nodal events, which may include the birth of a disabled child, abortion, migration, accident, unwanted or adolescent pregnancy, among others. Continuous unforeseen transitions to the family bring changes that influence routines and rituals. ${ }^{11}$

Thus, the present research had the following question: how would affected families perceive their routines and rituals in the post-disaster transition phase, considering the various life changes derived from such an event. The choice to use the narrative analysis method was aligned with the interpretive philosophical perspective, assuming the complex world of the experience of the families affected in the socio-environmental disaster, taking into account the changes in the life cycle. According to Schütze, ${ }^{12}$ the researchers of this line of thinking have the interpretative paradigm as an orientation, in which the interests are directed to the biographical interpretations of the subjects involved in their models of analysis.

The research followed the qualitative approach and was characterized by the study design of multiple cases, in which each family participant nucleus consisted of a case study. The case study is an empirical investigation that focuses on contemporary phenomena within their real-life context, especially when the boundaries between phenomenon and context are not clearly defined and the researcher has little or no control over the events or behaviors studied. ${ }^{13-14}$

The collection of the narratives started two years after the natural disaster and the fieldwork for data collection lasted nine months. Six families, totaling 12 adult individuals, ten children between zero and 12 years of age and three adolescents participated in the study. The inclusion criteria were defined as; family nucleus participants with children (children and adolescents), survivors of the 2008 disaster, and residents in the municipality belonging to the affected locality. The family nuclei were gradually included in the research as the data were collected and concomitantly analyzed from the beginning of the data collection. Sampling and data collection were finalized with the advancement of time spent in the field work, and from the production of narratives that denoted the saturation of the analysis related to the research question. The use of Schütze's guidelines ${ }^{15}$ for the autobiographical narrative interview contributed to the definition of the researcher's position while the family histories were heard. The interview, in the first meeting, began with the invitation to the members of the family to describe how was the day after the day of the disaster. The generating question: "How was the day after the day of the disaster?" resulted in narratives that later needed clarification and deepening of data, from questions that motivated the discussion of narrated aspects at another stage of the phase of data collection. It was noticed that the interviewees experienced moments of reflection and regained memories of the post-disaster period. Thus, the researcher's sensitivity to respecting the moment, valuing silence as a narrative, and also returning to the course of research, recapturing the interpretivetheoretic-philosophical presuppositions that guided him/her is of great value for the reliability of the narratives and the quality of data collection.

Thus, the main technique for obtaining narratives was the improvised narrative interview, adapted for the research with families, where they 
were considered narratives constructed by the members of the gathered family nuclei. Therefore, the argumentative moment of the narrative interview allowed clarifying and deepening aspects of the initial interviews, as well as the use of the genogram and ecomap tools to obtain data about the structure and relationships of the social network of the families. The use of such instruments in the qualitative research with families has frequently been used and it mainly covers research that collects the stories of family life. ${ }^{16}$ According to Schütze's autobiographical narrative interview technique, ${ }^{5}$ the questioning phase makes it possible for the researcher to direct the interview in order to deepen and clarify the details of the story in the face of the interviewer's narrative. Participant observation was used during the fieldwork, considering the successive visits to the locality during the research period and the participation of the researcher in moments of family life, in the meetings which had a total of five interviews with each nucleus. This observation made it possible to follow events in the post-disaster recovery process (the reconstruction of the house, daily household chores, meals with the participants, living with others in the community, for example); situations that motivated the participants' narratives.

\section{THE ADAPTATION OF STEPS FOR NARRATIVE ANALYSIS}

Next, the steps of applying the method of narrative analysis by Fritz Schütze, adapted for nursing research will be described. The method consists of six steps, the first being the formal text analysis, ${ }^{12}$ in which the selection and arrangement of the narrative passages describing the sequence of the events of each case were made, based on the formal indicators of the text, or rather, the textual markers for finalizing one segment and initializing the next. In the case of this research, the separation of the narrative segments from the non-narratives in the raw text from the transcript of each interview covered the segments of all the interviews, including the argumentative phase of the interviews, in which instruments adapted to the research with families were also used.

In the second step, a thorough analysis of each segment of the narrative previously selected from each interview was done, paying attention to what was being narrated and how each narrative was constructed. Such an analysis is called a structural description of the content, ${ }^{12,17}$ because the objective is also to identify the different procedural structures in the course of life. These procedural structures have been indicated and highlighted throughout each narrative segment for subsequent elaboration of analytical categories that characterize the indexed components (who did what, when, where and why).

The following section exemplifies the second stage of the analysis of the narrative of one of the families, which was obtained from the mother in the first interview.

[...] Everything changed, right? First, because I lost part of my family (-), then I had to rebuild this other side. We end up becoming more connected to who stayed behind and also worrying more, because I was not the only one who went through it [...] and also the financial part, because we are farmers and we lost a lot at the time. [Dramatic point] we had to start from scratch again. So it was a very (-) abrupt change. If I were to look back a year and a half ago today (-), I do not know if I would have imagined myself in this situation today [culminating situation], and there is the other side: I became the president of the association of the homeless here, [name of association]. And this allowed me to understand one side, not that I didn't know, because I have always participated in the community, I have always been involved and such (-), but so much more deeply than I didn't know, is the political side. So, I've been to Brasilia eight or nine times, I've been to Rio de Janeiro, I've been to São Paulo participating in an international seminar on humanitarian and disaster relief, so I ended up knowing the other side and I'm learning a lot from this. But this also affects my routine (-), having to leave and having to be away for four or five days or a week and someone having to stay with my daughter (-), so it was (-) it's a very big change and I never imagined that I would be able to go through such a big change, the way I'm going through it [...] [Family 4].

In this stage of the analysis of the narratives, the researcher already has a contextual understanding of the events that permeate the narrated history and, especially in regards to nursing research with families, the understanding of who the family is in terms of structure (personal characteristics of the members, roles and position in the family) become important for the autobiographical perspective of life experience, reflected in personal and collective constructions (family, community, social) of the interviewees.

In health and nursing research, there is usually a theoretical-philosophical foundation that locates it ontologically and epistemologically in order to leverage data discussion, the researcher makes deductions based on theory in the data analysis. In the present research, the issue relating to the care and the lives of the families was backed by the concepts of the Theory of Family Development, whose focus

* Symbols used in narratives: (-) pause in narration; $(>)$ Elevation in the tone of voice in the narration. 
is on the changes in life. In addition, the Theoretical Model of Family Routines and Rituals provided a theoretical-conceptual framework regarding the understanding of the daily family life in connection with health and disease.

The third step consisted of analytic abstraction, or rather, the interpreter distances themselves from the details of the structural description of the content shown in the narrative fragments in order to focus on "the abstract structural expressions of each period of life," in systematic relation with each other," $18: 7$ rebuilding history into a whole, from the dominant procedural structures in each life cycle to the present. Biographical trajectories is the term assigned to an analytical category that originates when the protagonist of the biography confronts the experience of losing his or her abilities to conduct his or her life intentionally due to external circumstances that force him to react as a process of suffering. ${ }^{3}$

Following the structural description of the contents of the narratives from all the interviews of each family, the segments of the stories about the family experience revealed poignant moments experienced by each family which outlined changes over time, in the moments before, during and after the disaster. For the reconstruction of the stories and the identification of trajectories each family in the time line, the abstract expressions referring to the ruptures, changes or adaptations in the familiar routine were raised, as well as changes related to the life cycle (transitions, alterations or adaptations in family tasks). To exemplify the analytic abstraction, the synthesis of the reconstruction of the history of one of the families can be seen (Figure 1).

The analytical abstraction of each case was continued, resulting in the reconstruction of their stories, which were organized along the time line and reflected the biographical trajectories of each family. "The people, while narrating their experience, open their discourse in such a way as to allow the apprehension of their meaning by other people." ${ }^{1: 427}$ The narratives relating to each case expressed the experiences and meanings particular to each family nucleus, even though the post-disaster transition experience was coincidental.

\section{Poignant life changing moment}

Before the disaster

Perception of the quiet life, with the arrival of the adoptive child to the family nucleus in acquisition and adaptation of this expected change in the families of origin.

\section{The 2 days of the disaster}

Dramatic point of change: unexpected losses with the death of the mother, sister and other extended family members. Rupture of family routine.
2 months post-disaster

Dramatic point of change: stay in shelter in the family home, accompanied by members of the family nucleus (maternal). Culminating moment: The family's task of coping with mourning. Difficulty in reestablishing routines, due to unpredictability regarding the return to the dwelling. External support in the individual family trajectory.
1 year and 6 months after the disaster

Return to the house. Dramatic point of change: Returning to the new task of restoring family ties and recovering losses in family farming property: Culminating moment: adaptation of family routine (and rituals) to family changes. Transformation of the individual family trajectory, with development of actions with the future in mind, participation and community representation for the families affected in the disaster.

\section{Figure 1 - Example of reconstructed history synthesis, referring to the case of family 4}

The fourth step recaptures the argumentative segments of the narratives and the theoretical explanations developed by the informants themselves, about their life history and identity in the current perspective, whose interest is in the importance of producing these theories for the course of life. It is the analysis of the knowledge that explores the nonindexed components, or rather the ways in which such theoretical constructions of the informants are reflected, the values, judgments. 
The analytical categories relating to the nonindexed components of narrative analysis are biographical self-description or theories about the self; explanatory theories; evaluation of the biographical trajectory or theory about the biography; explanations or background constructions; biographical projects, models or theories that guide action; abstract descriptions; general commented evaluations and theories. ${ }^{18}$ In each case of the families, narrative segments were identified which reflected some of the categories of non-indexed components mentioned above, and which deserved deepening of the analysis in the subsequent stage, in view of the objective of the study, which was to understand routines and rituals in the aftermath of disaster. The narrative segment of the mother of the family (case 4) is shown below to exemplify a non-indexed component, identified in the analytical category of background construction:

[Background construction] It's like I told you, on the one hand, it even helps me (-) I see that my pain is also the pain of other people and I know I can't be quiet (-), more than ever, we cannot stop, we have to put pressure on either our politicians, for the financial part that has been lost, the structure, or the mental health part (-), we see the amount of people who are depressed, who are using psychotropic medications, the amount of people who complain (-) time goes by and the hearts of people are on fire, then everything changes (-) and all this, whether we like it or not it goes to a politician: be it public health or an investment [...]. So, not that I feel obligated, but I feel good being able to defend a cause, because it is not just my thing (-) it is a thing of more people, for more people (-). And because I don't want my daughter, if I can avoid it, or as far as I can avoid it, let her go through the same suffering that I've gone through. [...] then, if I can, somehow, help her, others, and even myself to not go through it any more, for me it makes me feel good and makes me believe, once again, that life goes on, [...] (Family 4).

The background constructions can be defined as "affirmation in the general propositional mode, in whose content the historical situation shown in the narration has a meaning." $18: 226$ In other words, it is what lies behind the narrated content, or rather, the meaning attributed to the situation or experience judged by the holder of the biography.

Critical life situations are experiences that present themselves as a condition for the distortions and inconsistencies of the narrator of their history or biographer of their identity, built for a long period of time. The theoretical self-referrals also consist of the personal beliefs or characteristics of the narrators themselves, often perceived by them as strengths, although they should be seen as weaknesses.
The fifth step reached in the analysis of Schütze's narratives included the minimal contrastive comparison between the different cases, in search of similarities that intensify the categories that emerged in the previous stages of the analysis, taking into consideration the interest of the research. In a maximum contrastive comparison between the cases, differences were sought in order to confront the opposing categories and to highlight alternative procedural structures to understand the life history of the families affected by the natural disaster. Until this stage, the results of the comparative analysis identified were structured, based on the units of analysis related to the theoretical reference guide of the research, family routines and rituals. These results have been described and discussed theoretically.

The method of autobiographical narrative analysis proposes a sixth step for the construction of a theoretical model. The elaboration of the theoretical model starts from the systematic relation of the different categories of analysis confronted in the previous stages and of the respective theoretical reference. In the adaptation of the analysis, the present study did not conclude the analysis of the narratives in this stage, having described the categories of the analysis results from the interpretation in the previous phase, with the comparisons between the cases.

\section{CONCLUSION}

It is understood that the adaptation of the analysis method of autobiographical narratives in nursing research has been contemplated in the presented report, with a necessary contribution to the dissemination of the appropriate use of qualitative methodologies in the interpretive studies in the health area. In nursing, it is essential to search in order to understand the living process of people and families that represent the demands of health, giving care the core of professional practice, which is essential to human life.

With regard to the construction of Nursing Science, as well as to the theoretical-scientific and technological contributions to the health area, investigative processes that are dedicated to exploring different techniques and methods must be conducted, reproduced and criticized so that knowledge is disseminated and consolidated in innovative practices and is beneficial to society.

Narratives as elements of analysis are strongly defended in the scientific literature and require the use of a systematic structure for their apprehension and analysis. With regard to the approach used 
in narrative analysis, it is possible to point out as advantages that, in the method, the author details the interview and analysis steps, which contributes to the researcher being more confident in following the steps both in the interview and narrative analysis. The specificity and tradition of nursing research with families allowed for the addition of tools to the narrative interview that promoted discussion and the deepening of narratives, even though the mixture of techniques is not directly indicated by the author. In terms of disadvantages, it is important to note that the language is very specific and based on the author's long experience of the method, therefore in order for the researcher to use the method, the researcher must have a deep understanding of theoretical bases and have experience in qualitative research.

It is concluded that this method offers support for interviews and in-depth analysis of health and disease narratives and their social context. The potential of the application of this method in nursing research highlights the unveiling of attitudes and life changes in the face of crisis and suffering, based on the experiences of individuals in groups such as families and community, limiting itself to the possibility of the elaboration of theoretical models insofar as the set of analyzed data presents sufficiency for generalizations regarding the unit of analysis. In these terms, it is considered that the method shared here, offers a dialogical opening with the experience of others, without losing sight of the scientific rigor and commitment to the construction of conceptual theories or models that expand the knowledge of the different areas.

\section{REFERENCES}

1. Silva DGV, Trentini M. Narrativas como técnica de pesquisa em enfermagem. Rev Latino-am Enfermagem [Internet]. 2002 Mai-Jun [cited 2015 Jul 20]; 10(3):423-32. Available from: http://www. revistas.usp.br/rlae/article/viewFile/1675/1720

2. Weller W. Tradições hermenêuticas e interacionistas na pesquisa qualitativa: a análise de narrativas segundo Fritz Schütze. [Internet] [s.d.] [cited 2015 jul 20]. Available from: http://www.anped.org.br/ reunioes/32ra/arquivos/trabalhos/GT14-5656-Int.pdf

3. Appel M. La entrevista autobiográfica narrativa: fundamentos teóricos y la praxis del análisis mostrada a partir del estudio de caso sobre el cambio cultural de los Otomíes en México. Forum: Qualitative Social Research Sozial for schung [Internet]. 2005 [cited 2016 Oct 26] 6(2):1-23. Available from: http://www. qualitative-research.net/index.php/fqs/article/ viewFile/465/995
4. Schütze F. Ärtzliche vermittlungs und beratungsmuster im kontext lebensbedrohlicher erkrankungenund ihre pädagogigsche sensibilität. die pädagogigschen komponentender ärtzlicheprofessionellen informations-beratungs und betreuugsarbeit bei herzinfart und brustkrebspatienten. [Internet] [cited 2016 Oct 26] Gepris DFG. Available from: http://gepris.dfg.de/ gepris/projekt/98219139

5. Bauer MW, Gaskell G. Pesquisa qualitativa com texto, imagem e som: um manual prático. $2^{\mathrm{a}}$ edição. Petrópolis (RJ): Vozes; 2002.

6. López YAA, Trad LAB. "Antes e depois da LMC": experiências e dimensões da leucemia mieloide crônica como uma ruptura biográfica. Cad Saúde Pública [Internet]. 2014 [cited 2016 Oct 26] 30(10):2199208. Available from: http://www.scielo.br/pdf/csp/ v30n10/0102-311X-csp-30-10-2199.pdf

7. Willig MH. As histórias de vida dos idosos longevos de uma comunidade1: o elo entre o passado e o presente [tese]. Curitiba (PR): Universidade Federal do Paraná, Programa de Pós-graduação em Enfermagem; 2012.

8. Fernandes GCM, Boehs AE. Rotinas de cuidado em relação à saúde de famílias em transição após um desastre natural. Rev Latino-am Enfermagem [Internet]. 2013 Jul-Ago [cited 2016 Oct 26]; 21(4):1-8. Available from: http://www.redalyc.org/articulo. oa?id=281427992021

9. Roque ATF, Carraro TE. Narrativas sobre a experiência de ser puérpera de alto risco. Esc Anna Nery [Internet] 2015 Abr-Jun [cited 2015 Jul 20]; 19(2):272-8. Available from: http://www.scielo.br/pdf/ean/v19n2/14148145-ean-19-02-0272.pdf

10. Meincke SMK, Carraro TE. Vivência da paternidade na adolescência: sentimentos expressos pela família do pai adolescente. Texto Contexto Enferm [Internet]. 2009 Jan-Mar [[cited 2015 Jul 20]; 18(1):83-91. Available from: http://www.scielo.br/pdf/tce/v18n1/ v18n1a10

11. Mc Goldrick M, Shibusawa T. O ciclo vital familiar. In: Walsh F. Processos normativos da família: diversidade e complexidade. $4^{\text {a }}$ ed. Porto Alegre (RS): Artmed; 2016.

12. Schütze F. Pesquisa biográfica e entrevista narrativa. In: Weller V, Pfaff N. Metodologias da pesquisa qualitativa em educação: teoria e prática. Petrópolis (RJ): Vozes; 2010. p. 211-22.

13. Yin RK. Estudo de caso: planejamento e métodos. $3^{\text {a }}$ edição. Porto Alegre (RS): Bookman; 2005.

14. Yin RK. Aplications of case study research. Thousand Oaks (US): Sage Publications; 1993.

15. Schütze F. Biography analysis on the empirical base of autobiographical narratives: how to analyse autobiographical narrative interviews part two. European Studies on Inequalities and Social Cohesion [Internet]. 2008 [cited 20 Jul 2015]; Available from: http:/ / www.profit.uni.lodz.pl/index.php?idk=265 
16. SouzaIP, Bellato R, AraújoLFS, Almeida KBB.Genogram and eco-map as tools for understanding family care in chronic illness of the young. Texto Contexto Enferm, 2016 [cited 2016 Oct 26]; 25(4):e1530015 Available from: http:/ / www.scielo.br/scielo.php?pid=S010407072016000400301\&script=sci_abstract\&tlng=pt

17. Schütze F. Biographical counselling in rehabilitative vocational training. Part 2 [Module B.2.2], Biography analysis on the empirical base of autobiographical narratives - how to analyse autobiographical narratives interviews [Internet]. Magdeburg: Univ., insges; 2007 [cited 2015 Jul 20]. p. 1-51. Available from: http://www.uni-magdeburg.de/zsm/projekt/ biographical/1/B2.2.pdf
18. Schütze F. Biographical counselling in rehabilitative vocational training. Part 1 [Module B.2.1], Biography analysis on the empirical base of autobiographical narratives - how to analyse autobiographical narratives interviews [Internet]. Magdeburg: Univ., insges; 2007 [cited 2015 Jul 20]. p. 1-64. Available from: http://www.uni-magdeburg.de/zsm/projekt/ biographical/1/B2.1.pdf

19. Betts S, Griffiths A, Schütze F, Straus P. Biographical counselling: an introduction. european studies on inequalities and social cohesion [Internet]. 2008 [cited 2015 Jul 20]; (1). Available from: http:/ / www.profit. uni.lodz.pl/index.php?idk=265 